\title{
Exploring the Role of Training in Promoting Students' Peer-Feedback Including Critical Peer-Feedback
}

Fatma Kaya, PhD

Dicle University, Diyarbakur, Diyarbakur Province, Turkey

(iD https://orcid.org/0000-0002-4040-0194

Zeynep Yaprak, PhD

Dicle University, Diyarbakur, Diyarbakur Province, Turkey

Contact: fatma.hayta@dicle.edu.tr

\section{Abstract}

The question of how critical-thinking skills could be integrated into English as a Foreign Language (EFL) pedagogy has been one of the main concerns in the field of language teaching and learning as they have a great potential to increase the quality of learning and teaching. The purpose of this study was to investigate whether training based on peer feedback, including critical feedback, contributes to participants' peer feedback and critical feedback performances. The participants, who were undergraduate English Language Teaching (ELT) students $(n=40)$, were exposed to an 8-week training program in which several feedback criteria, including critical ones, were introduced to them. Data obtained from the participants' pre-test and post-test peer feedback performances and semi-structured interviews were analyzed by using SPSS and content analysis, respectively. The results revealed that the training improved performance in providing peer feedback, including critical peer feedback. Finally, learners reported satisfaction with the training program, although some challenges were encountered in the process.

Keywords: L2 writing; peer feedback; critical peer feedback; critical thinking

Date Submitted: March 28, 2020 | Date Published: November 3, 2020

\section{Recommended Citation}

Kaya, F., \& Yaprak, Z. (2020). Exploring the role of training in promoting students' peer-feedback including critical peerfeedback. Journal of Educational Research and Practice, 10, 377-392.

https://doi.org/10.5590/JERAP.2020.10.1.24

\section{Introduction}

In recent decades, the concept of critical thinking has been widely investigated in the field of language teaching and learning as it is often associated with successful language learning (Golpour, 2014). Paul and Elder (2008, as cited in Indah, 2017) stated that critical-thinking skills and language skills are highly interrelated in that successfully conveying a written or spoken message is an indicator of one's employment of critical-thinking skills. Regarding writing in a second language (L2), learners are encouraged to make use of several critical-thinking skills because successful writing depends on how well these skills are employed by the writer (Moghaddam \& Malekzadeh, 2011). Peer feedback, one of the key components of successful L2 writing and the main focus of this study, is also essential and thought to contribute to learners' critical-thinking skills 
(Lu \&Bol, 2007; Yang et al., 2006). A close relationship exists between peer feedback and critical thinking; peer feedback requires learners to apply higher-order thinking, including reflection and problem solving, which are subsumed under critical-thinking skills. Furthermore, the quality of peer feedback is often measured with its degree of criticality (Bijami et al., 2013; Farrah, 2012; Choy \& Cheah, 2009; Nilson, 2003); however, it should be noted that critical thinking is a broad concept entailing numerous skills, including analyzing, evaluating, and organizing (Hitchcock, 2017). Elder (2007) indicated that critical thinkers are those who are capable of monitoring, examining, and revising their thinking. On the other hand, Halpern (1999, p. 70) asserted that critical thinking "refers to the use of cognitive skills or strategies that increase the probability of a desirable outcome.... it is purposeful, reasoned and goal-directed.” Although various definitions have been proposed for critical thinking, they all prioritize the following abilities as major components of critical thinking: "problem identification and analysis, clarification of meaning, gathering the evidence, assessing the evidence, inferring conclusions, considering other relevant information, and making an overall judgment" (Hitchcock, p. 477).

According to Floyd (2011), achieving critical thinking is much more demanding for students in L2 classes since they must do so while learning a second language. Furthermore, critical thinking has often been associated with Western culture. Also worth noting is that students' inefficiency in L2 is likely to have a negative impact on promoting critical thinking in foreign language classes (Atkinson, 1997; Floyd); however, several studies have made it clear that critical thinking and language learning are highly interrelated, and the need for integrating critical-thinking skills into language classes is obvious (Liaw, 2007; Rashid \& Hasim, 2008; Nikoopour et al., 2011). These skills can enable students to implement what they learn in different contexts and situations, which is one of the desired learning outcomes in a pedagogical context (Elfatihi, 2017).

\section{Literature Review}

\section{Critical Thinking and L2 Writing}

Improving L2 writing is more demanding than improving other basic language skills for students since learners must consider various issues, including writing conventions, accurate language usage, target audience, and communicative goals (Raimes, 2002; Olshtain, 2001; Polio \& Williams, 2009). Furthermore, to create a piece of writing in L2 requires critical-thinking skills (Golpour, 2014). Especially in argumentative writing, learners must employ critical thinking, identify and eliminate contradictory statements, and evaluate sound pieces of evidence to support their ideas (McKinley, 2013). As such, argumentative writing reveals whether students have certain critical thinking skills or not, and, therefore, is chosen for assessing their critical thinking in L2 writing (Stapleton, 2001; Indah, 2017). To measure EFL (English as a foreign language) students' critical thinking in writing, Stapleton (p. 515) proposed a model that included the following features of critical thinking:

- Argument: It refers to the judgment the author arrives at regarding a matter as a result of specific evidence. The writer does not have to take a side through agreeing or disagreeing; a judgment that indicates hesitance and recognizes and discusses both sides equally by providing sound evidence for the hesitance is also accepted as an argument (Browne \& Keeley, 1994, as cited in Stapleton).

- Evidence: It refers to the proof the author presents to increase the strength of an argument by providing it with a valid ground. There are many types of proofs the author may utilize, such as statistics, personal experiences, analogies, references to authorities, and academic studies (Browne \& Keeley, 1994; Leki, 1995; Ramage \& Bean, 1999, all as cited in Stapleton).

- Recognition/Refutation of Opposition: This concept is related to how the author reacts to the versatility of a matter. In fact, the author is expected to acknowledge alternative points related to the 
issue he/she has already arrived at a conclusion for as well as to discuss those points and refute them with logical reasons (Ramage \& Bean, 1999, as cited in Stapleton).

- Fallacies: Fallacies occur when the author fails to promote logic within the reasons he/she provides, thereby making the argument flawed. They include oversimplification, overgeneralization/hasty generalization, irrelevancy, and begging the question. Detecting fallacies is often challenging since individual perspectives are at play; a statement which is considered logical by one individual can be considered illogical by another, which calls for a universal standard. The sole criterion to determine whether there is fallacy within an argument is to look for the degree of relevancy between the conclusion and reason(s) provided (Browne \& Keeley, 1994; Leki, 1995; Ramage \& Bean, 1999, all as cited in Stapleton).

\section{L2 Writing and Peer Feedback}

The vital role of feedback, including peer feedback in L2 writing pedagogy, cannot be denied since the author has the opportunity to realize others' perspectives related to the author's writing, which has the potential to provide the writer with guidance in the writing process (Chen, 2010). Therefore, its usage is highly popular in the context of foreign language education, especially in higher levels (Huisman et al., 2018). Providing and receiving peer feedback has proved to contribute to students' writing proficiency in various aspects (Lin \& Chien, 2009; Kamimura, 2006; Diab, 2010; Lundstrom \& Baker, 2009; Zhao, 2010; Berggren, 2015). Peer feedback has also been regarded as a "potentially valuable aid for its social, cognitive, affective, and methodological benefits" (Rollinson, 2005, p. 23). Receiving peer feedback is considered more advantageous compared to receiving teacher feedback, as learners have similar problems and go through similar processes. Thus, it could be easier for learners to understand comments provided by their peers (Cho \& MacArthur, 2010). Overall, providing peer feedback has several benefits for learners. For example, students' selfconfidence and motivation increase when they are given the responsibility of editing another individual's written work (Lin \& Chien). In addition, students become more attentive to the issues related to writing specifications and evaluation processes when they are required to give peer feedback (Huisman et al.). Lastly, students who give peer feedback are more likely to recognize the common problems and limitations in their own work and thus become more critical towards their writing (Rollinson; Cao et al., 2019).

Although peer feedback has proved to contribute to students' writing proficiency, it is not without its shortcomings: Giving high-quality and useful feedback is a demanding job on the part of the learner, as the learner must go through several advanced cognitive processes to provide it. Moreover, students may be hesitant to give feedback since it could damage relationships with their friends (Wang, 2014). Therefore, students need training to better cope with and address the challenges of providing peer feedback. In fact, several studies have focused on training on peer-feedback (Hu, 2005; Min 2006; Lam, 2010; Crinon, 2012; Rahimi 2013); the results have shown that peer feedback training improves students' peer feedback practices. Lastly, several studies were conducted to investigate whether and how peer feedback could foster criticalthinking skills of students using digital platforms (Lu \& Bol, 2007; Novakovich, 2016), which have had positive results. However, in this study, how students' peer feedback performances, including critical feedback, could be improved was investigated in a class where critical reading and writing were the main focus. To this end, the researchers posed the following questions:

- How does peer feedback training affect students' peer feedback performances?

- How does peer feedback training affect students' critical peer feedback performances?

- Is there a relationship between students' peer feedback performances and writing proficiency?

- What are the students' views on the peer feedback training in the critical reading and writing class? 


\section{Method}

In this study, the researchers used a single group pre-test/post-test research design, a quasi-experimental design, to answer the research questions.

\section{Setting and Participants}

We conducted the study at a state university in Turkey. Participants $(n=40)$ consisted of sophomores majoring in the English Language Teaching (ELT) department. They were selected by convenience sampling, meaning only the students who attended the critical reading and writing class regularly and participated in peer feedback sessions were included in the study. Of the 40 participants, eight were interviewed after the training. Since the participants took a writing skills class during the academic year as freshmen students, they were supposed to be familiar with essay writing and have basic language skills. In the critical reading and writing class, students were expected to go one step beyond the basic reading and writing program by taking a critical stance toward their skills. To this end, the instructor introduced several critical-thinking skills, including "problem identification and analysis, clarification of meaning, gathering the evidence, assessing the evidence, inferring conclusions, considering other relevant information, and making an overall judgment" (Hitchcock, 2017, p. 477). Genres like argumentative and response essays, which require students to employ critical thinking, were taught in the class. Lastly, students were required to evaluate and give feedback on each other's argumentative essays and expected to employ several critical-thinking skills in the process.

\section{Data Collection and Analysis}

The study was conducted during the participants' critical reading and writing class in the fall term. Throughout the semester, participants wrote a variety of essays (e.g., response, argumentative essays) and underwent an eight-week training program on how to give peer feedback, including critical peer feedback. Before the training, participants were asked to give peer feedback on each other's argumentative essays in the class, which was considered a pre-test. In their first feedback, the criteria to consider while giving peer feedback were not made explicit to the participants; they were free to decide which aspects of the essay to focus on. After the pre-test, the participants underwent the training program, in which the instructor introduced the criteria for peer feedback and modeled them in the class. Throughout the training, participants provided peer feedback on three occasions based on the criteria introduced to them. For the post-test, with consideration given to the criteria taught during training (Table 1), participants provided in-class peer feedback for the same argumentative essays they originally reviewed during the pre-test. 
Table 1: Training Schedule

\begin{tabular}{lll}
\hline Pre-test & Session & Learning Activities \\
\hline Training & $\begin{array}{l}\text { Giving peer feedback on the argumentative essays without } \\
\text { training }\end{array}$ \\
\cline { 2 - 3 } & $\mathbf{2}$ & Introduction of the criteria for peer feedback \\
\hline 4 & Applying the criteria of mechanical details to examples \\
\hline 5 & $\begin{array}{l}\text { Determining how to provide comments related to structure and } \\
\text { organization of an essay }\end{array}$ \\
\cline { 2 - 3 } & Practicing critical comments \\
\cline { 2 - 3 } & $\mathbf{7}$ & Providing directive feedback \\
\hline 8 & 1st time: applying all criteria to a peer's essay \\
\cline { 2 - 3 } & 9 & 2nd time: applying all criteria to a peer's essay \\
\hline Post-test & 10 & Repeating the pre-test with all feedback criteria \\
\hline Follow-up Interview & 11 & Sharing views on training and learning experiences \\
\hline
\end{tabular}

While deciding on the feedback criteria, we considered several models (Novakovich, 2016; Working Document, 2015). For the critical peer feedback dimension, we favored Stapleton's model (2001), which was mentioned above. The following criteria were introduced to the participants during the training:

- Comments related to mechanical details: these comments included statements related to grammar, sentence structure, punctuation, etc. The feedback provider searched for correctness by asking various questions. For example, are complete sentences used? (S-V-O), are punctuation marks used correctly? Is there any problem related to tense agreement?

- Comments related to the structure and organization of the essay: these comments primarily involved the essentials of writing an essay and were prompted by the following questions: Is the text coherent? Is there only one main idea per paragraph? Do the details support the main idea?

- Comments related to the content of the essay (critical comments): critical comments, comprising the core of the study, focused on the content of an essay and required students to take a critical stance towards said content. The feedback provider evaluated the content of the essay by answering the following questions: What is the argument (message)? Is it clearly presented? Are sufficient facts, explanations, examples, and explanations provided? Does the author recognize/refute the opposing points successfully? Have you noticed any fallacies in the essay?

- Comments for improvement of the essay (directive): these statements included suggestions to help the authors improve their essays. Suggestions could be related to any component of the essay, ranging from the organization to the content.

Participants were instructed to give peer feedback based on the aforementioned criteria. For each criterion, they were expected to answer five questions, for a total of twenty questions, which were provided as a checklist. The participants' feedback performances were evaluated based on their ability to answer these questions. While 5 was accepted as the highest performance score, o was considered the lowest in 
performance for each criterion and overall performance. To ensure reliability, the participants' feedback papers were evaluated by two raters, and an agreement in terms of feedback scoring by the raters was revealed.

We employed qualitative and quantitative data collection tools in the study. Statistical data obtained through SPSS (Statistical Package for Social Sciences) was supported with interview data. To determine if any differences in the participants' pre-test and post-test peer feedback performances existed for each category mentioned above and their overall feedback performances, we employed paired-sample $t$-tests. In addition, we used the Pearson correlation test to determine any relationship between the participants' writing performance (the last essay written by students at the end of the semester) and their feedback performance (their last feedback/post-test). Lastly, eight of the participants were interviewed after the training to get an indepth understanding of their views about peer feedback, including the benefits and challenges associated with it. We used content analysis to analyze the interview data. An inductive approach was followed, which included the steps of open coding, creating categories, and abstraction (Elo \& Kyngas, 2008). First, responses obtained from participants were analyzed and eliminated by the researchers with respect to the research focus. After open coding, categories were created and listed in relation to the interview questions. Participants' first language (L1) was preferred to conduct the interviews to prevent any misunderstanding and ambiguity that could emerge because of students' incompetency in L2.

\section{Findings}

In this section, we present results of the quantitative and qualitative data analysis, respectively.

\section{Participants' Pre-Test/Post-Test Peer Feedback Performances}

As shown in Table 2, issues related to structure and organization of the essay were mostly evaluated by participants during the pre-test, which was followed by feedback related to mechanical details. Directives were the least performed criterion by participants in the pre-test. The order did not change in the post-test performances, although there were considerable differences in the mean scores of feedback provided by the participants for each criterion in the pre-test and post-test performances.

Table 2: Descriptive Statistics of the Participants' Peer Feedback Performances for Each Criterion

\begin{tabular}{|c|c|c|c|c|c|}
\hline & & Mean & $\mathbf{N}$ & $\begin{array}{l}\text { Std. } \\
\text { Deviation }\end{array}$ & $\begin{array}{l}\text { Std. Error } \\
\text { Mean }\end{array}$ \\
\hline \multirow{2}{*}{$\begin{array}{c}\text { Mechanical } \\
\text { Details }\end{array}$} & \multirow{2}{*}{$\begin{array}{l}\text { Pre-test } \\
\text { Post-test }\end{array}$} & 0,93 & 40 & 1,185 & ,187 \\
\hline & & 4,05 & 40 & ,932 & 147 \\
\hline \multirow{2}{*}{$\begin{array}{c}\text { Structure \& } \\
\text { Organization }\end{array}$} & Pre-test & 1,55 & 40 & ,959 & ,152 \\
\hline & Post-test & 4,63 & 40 & ,628 & ,099 \\
\hline \multirow{2}{*}{$\begin{array}{c}\text { Critical } \\
\text { Comments }\end{array}$} & Pre-test &, 78 & 40 & ,733 & ,116 \\
\hline & Post-test & 3,75 & 40 & ,899 & ,142 \\
\hline \multirow{2}{*}{ Directives } & Pre-test & ,13 & 40 & ,335 & ,053 \\
\hline & Post-test & ,93 & 40 & ,656 & 104 \\
\hline
\end{tabular}

A paired-samples $t$-test was applied to determine whether there was any significant difference between students' in-class peer feedback performances with regard to mechanical details in the pre- and post-test. As shown in Table 3, the biggest gap between the pre- and post-test performances was observed in the criterion of 
mechanical details, with the mean difference $M D=3,125$. There was a significant difference between participants' pre- and post-test performances with $t(39)=13,12$ and $p$-value $=0.000$, meaning that participants were far better in their post-test performances compared to their pre-test performances in terms of providing peer feedback related to mechanical details, including sentence structure, grammar, punctuation, etc.

Table 3: Comparison of Participants' Peer Feedback Performance Regarding Mechanical Details in Pre/Post-Tests Using a Paired-Samples t-Test

\begin{tabular}{|c|c|c|c|c|c|c|c|c|}
\hline & \multicolumn{5}{|c|}{ Paired Differences } & \multirow[t]{3}{*}{$\mathbf{t}$} & \multirow[t]{3}{*}{ df } & \multirow{3}{*}{$\begin{array}{l}\text { Sig. (2- } \\
\text { tailed) }\end{array}$} \\
\hline & \multirow[t]{2}{*}{ Mean } & \multirow[t]{2}{*}{$\begin{array}{l}\text { Std. } \\
\text { Deviation }\end{array}$} & \multirow[t]{2}{*}{$\begin{array}{l}\text { Std. } \\
\text { Error } \\
\text { Mean }\end{array}$} & \multicolumn{2}{|c|}{$\begin{array}{l}95 \% \text { Confidence } \\
\text { Interval of the } \\
\text { Difference }\end{array}$} & & & \\
\hline & & & & Lower & Upper & & & \\
\hline $\begin{array}{l}\text { Pair I } \\
\text { Pre-/ } \\
\text { Post- } \\
\text { Test }\end{array}$ & $-3,125$ & 1,505 &, 238 & $-3,606$ & $-2,644$ & $-13,129$ & 39 & , o00 \\
\hline
\end{tabular}

As illustrated in Table 4, the second greatest difference between participants' pre- and post-test performances was observed in the category of structure and organization with mean difference $M D=3,075$. It was also revealed that the difference was significant with $t(39)=\mathrm{v} 20,02$ and $p$-value $=0.000$, supporting the inference that participants were more successful in providing peer feedback related to structure and organization in their post-test papers.

Table 4: Comparison of Participants Peer Feedback Performance

\begin{tabular}{|c|c|c|c|c|c|c|c|c|}
\hline & \multicolumn{5}{|c|}{ Paired Differences } & \multirow[t]{3}{*}{$\mathbf{t}$} & \multirow[t]{3}{*}{ df } & \multirow{3}{*}{$\begin{array}{l}\text { Sig. (2 } \\
\text { tailed) }\end{array}$} \\
\hline & \multirow[t]{2}{*}{ Mean } & \multirow[t]{2}{*}{$\begin{array}{l}\text { Std. } \\
\text { Deviation }\end{array}$} & \multirow[t]{2}{*}{$\begin{array}{l}\text { Std. } \\
\text { Error } \\
\text { Mean }\end{array}$} & \multicolumn{2}{|c|}{$\begin{array}{l}\text { 95\% Confidence } \\
\text { Interval of the } \\
\text { Difference }\end{array}$} & & & \\
\hline & & & & Lower & Upper & & & \\
\hline $\begin{array}{l}\text { Pair I } \\
\text { Pre-/ } \\
\text { Post- } \\
\text { Test }\end{array}$ & $-3,075$ & ,971 & ,154 & $-3,386$ & $-2,764$ & $-20,028$ & 39 & , OOO \\
\hline
\end{tabular}

In regard to participants' performances in the category of content (critical comments), the primary concern of the study, results revealed that students became more successful in evaluating the content of the essay they revised after the training; a significant difference $(p$-value $=0.000)$ was found between the pre- and post-test performances of the participants with $M D=2,97$ and $t(39)=15,56$, as shown in Table 5 . However, only a few students identified and talked about the fallacies in the essay they evaluated, while the majority 
commented on the argument, supporting ideas and recognition/refutation of opposing points as revealed in their post-test performances:

"The argument is not stated clearly: you discussed both parts including why marijuana should be legal and illegal, but I could not understand your point here. It would be better if you were clear about your position even if you were neutral" (feedback provided by P12 on an essay in which the author discussed the legality of marijuana).

"Since the essay is about plastic surgery, I was expecting to read about some real experiences people had and their opinions on whether they suggested plastic surgery or not, which would make the essay more interesting and convincing; however, the essay mostly included explanations and technical information about plastic surgery, which made it boring and weak" (feedback provided by P35 on an essay in which the author discussed the benefits of plastic surgery).

"I did not like the statement that 'undoubtedly, they (homosexual people) would not choose homosexuality'. It is a hasty generalization written emotionally and far from proving" (feedback provided by P4O on an essay in which the author discussed discrimination against the LGBT community).

"I did not like the argument (topic) since the topic is not open to discussion; it is a matter of personal choice" (feedback provided by $\mathrm{P} 43$ on an essay in which the author supported the idea that women should dye their hair).

"I do not agree with the statement that 'homeschooling does not respond to a child's needs'. I think there is an oversimplification because there are many important figures in the history who did not complete formal education" (feedback provided by $\mathrm{P} 17$ on an essay in which the author was against homeschooling).

"I did not like the refutation part: Even though you recognized the opposing point successfully, you were not able to refute it convincingly. Just giving personal opinions and not providing any evidence, examples, or experiences does not make the reader believe what you claim" (feedback provided by P1o on an essay in which the author questioned the purpose of human existence).

Table 5: Comparison of Participants Peer Feedback Performance Regarding Content in Pre-/Post-Tests Using a Paired-Samples t-Test

\begin{tabular}{|c|c|c|c|c|c|c|c|c|}
\hline & \multicolumn{5}{|c|}{ Paired Differences } & \multirow[t]{3}{*}{$\mathbf{t}$} & \multirow[t]{3}{*}{ df } & \multirow{3}{*}{$\begin{array}{l}\text { Sig. (2- } \\
\text { tailed) }\end{array}$} \\
\hline & \multirow[t]{2}{*}{ Mean } & \multirow[t]{2}{*}{$\begin{array}{l}\text { Std. } \\
\text { Deviation }\end{array}$} & \multirow[t]{2}{*}{$\begin{array}{l}\text { Std. } \\
\text { Error } \\
\text { Mean }\end{array}$} & \multicolumn{2}{|c|}{$\begin{array}{l}\text { 95\% Confidence } \\
\text { Interval of the } \\
\text { Difference }\end{array}$} & & & \\
\hline & & & & Lower & Upper & & & \\
\hline $\begin{array}{l}\text { Pair I } \\
\text { Pre-/ } \\
\text { Post- } \\
\text { Test }\end{array}$ & $-2,975$ & 1,209 & ,191 & $-3,362$ & $-2,588$ & $-15,567$ & 39 & , OOO \\
\hline
\end{tabular}


Table 6 shows how participants performed in the last category: directives, before and after the training. The least significant difference was found between students' pre- and post-test performances in the category of directives as $M D=, 800$, and $t(39)=6$, 99 with $p$-value $=$, 000 .

Table 6: Comparison of Participants Peer Feedback Performance Regarding Directives in Pre-/Post-tests Using a Paired-Samples t-Test

\begin{tabular}{|c|c|c|c|c|c|c|c|c|}
\hline & \multicolumn{5}{|c|}{ Paired Differences } & \multirow[t]{3}{*}{$\mathbf{t}$} & \multirow[t]{3}{*}{ df } & \multirow{3}{*}{$\begin{array}{l}\text { Sig. (2- } \\
\text { tailed) }\end{array}$} \\
\hline & \multirow[t]{2}{*}{ Mean } & \multirow[t]{2}{*}{$\begin{array}{l}\text { Std. } \\
\text { Deviation }\end{array}$} & \multirow[t]{2}{*}{$\begin{array}{l}\text { Std. } \\
\text { Error } \\
\text { Mean }\end{array}$} & \multicolumn{2}{|c|}{$\begin{array}{l}\text { 95\% Confidence } \\
\text { Interval of the } \\
\text { Difference }\end{array}$} & & & \\
\hline & & & & Lower & Upper & & & \\
\hline $\begin{array}{l}\text { Pair I } \\
\text { Pre-/ } \\
\text { Post- } \\
\text { Test }\end{array}$ &,- 800 &, 723 & ,114 & $-1,031$ &,- 569 & $-6,996$ & 39 & ,ooo \\
\hline
\end{tabular}

Besides the comparison of the participants' performances in each category, their overall peer feedback performances before and after the training were compared. As displayed in Table 7 , there was an improvement in peer feedback performances after the training; $p$-value was found as ,ooo with $M D=2,50$, and $t(39)=22,31$.

Table 7: Comparison of Participants' Overall Peer Feedback Performance in Pre-/Post-tests Using a Paired-Samples t-Test

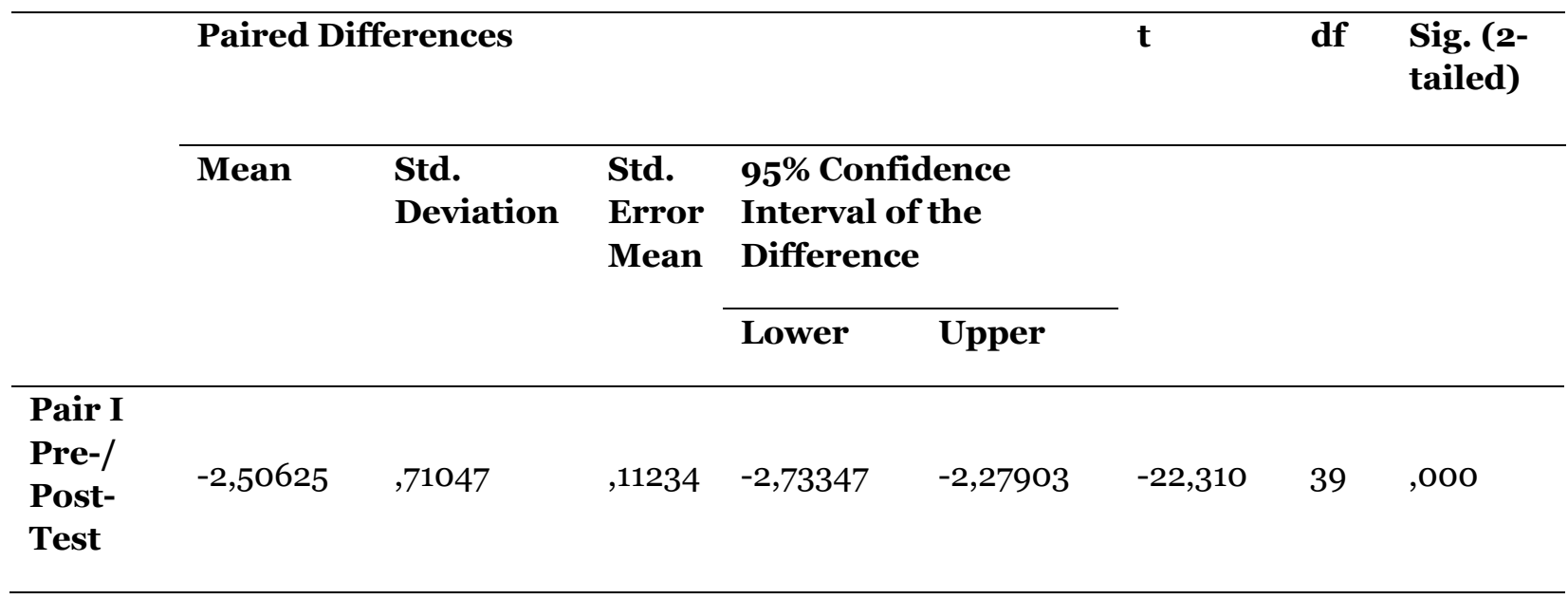

\section{Relationship Between Participants' Peer Feedback Performance and Writing Performance}

To determine whether the participants' writing performance (last essay performance) and peer feedback (last feedback/post-test) performance were related to each other, a Pearson correlation test was applied. A positive 
correlation between participants' success in writing and providing peer feedback was revealed, which suggests that those who were successful in essay writing were also good at providing high-quality feedback to their peers, with $p$-value $=, 003$ as demonstrated in Table 8 .

Table 8: Relationship Between Participants' Peer Feedback Performance and Writing Performance Using a Pearson Correlation Test

\section{Peer Feedback Writing Performance Performance}

\begin{tabular}{llcc}
\hline $\begin{array}{l}\text { Peer Feedback } \\
\text { Performance }\end{array}$ & \multicolumn{2}{l}{ Pearson Correlation } &, $453^{* * *}$ \\
\cline { 2 - 4 } & Sig. (2-tailed) & - &, 003 \\
\cline { 2 - 4 } & $\mathrm{N}$ & 40 & 40 \\
\hline $\begin{array}{l}\text { Writing } \\
\text { Performance }\end{array}$ & Pearson Correlation &, $453^{* * *}$ & - \\
\cline { 2 - 4 } & Sig. (2-tailed) &, 003 & 40 \\
\cline { 2 - 4 } & $\mathrm{N}$ & 40 & \\
\hline
\end{tabular}

** Correlation is significant at the 0.01 level (2-tailed).

\section{Participants' Views on the Feedback Practices}

To confirm the statistical data and have a thorough understanding of the training process, we asked eight participants to evaluate the process by answering several questions related to the training. First, they were asked to compare their first peer feedback process and the last one in any aspect. There was agreement among the participants $(n=6)$ in that the first feedback session was quite challenging as they did not know which criteria they needed to consider since there was much to evaluate in the essays and time was limited. Conversely, the last peer feedback session was easier since the instructor made the criteria explicit during the training. Nearly all of the participants $(n=7)$ stated that in the first feedback session, they evaluated the essays in terms of structure (grammar) and organization, whereas in the last peer feedback session, they also attempted to evaluate the content (e.g., the main argument, supporting ideas, and refutation in terms of their strength, and reliability).

Participants were also asked to describe whether giving peer feedback helped improve their academic reading and writing skills. As shown in Table 9, a good number of benefits were reported by the participants as a result of providing peer feedback on each other's essays. Most interviewees $(n=7)$ claimed that giving feedback increased their awareness about the mistakes encountered in a peer's paper and helped them avoid making such mistakes in their own essays. A fair number of participants $(n=5)$ indicated that evaluating the content of a peer's essay enabled them to pay attention to issues like strength of an argument, reliability, representativeness, and persuasiveness of pieces of evidence in their own writing assignments, which led them to conduct intensive research about the topics of their essays to strengthen their arguments and supporting statements. Half of the participants $(n=4)$ confirmed that giving peer feedback also improved their research skills by helping them develop a critical attitude towards the sources of information used. In addition, several participants $(n=3)$ stated that peer feedback enabled them to question the peer's argument in the essay, which led them to have different perspectives about the essay topic. 
Table 9: Benefits of Giving Peer Feedback to Participants' Academic Reading and Writing Skills

\begin{tabular}{ll}
\hline Answers & Number of Participants \\
\hline $\begin{array}{l}\text { Avoiding the mistakes encountered in peer's essay in their own } \\
\text { writing }\end{array}$ & P1, P2, P3, P4, P5, P6, P7 \\
\hline $\begin{array}{l}\text { Stimulating students to focus on how to make their argument } \\
\text { stronger in their writing assignments through searching for and } \\
\text { eliminating among the supporting statements found (evidences, } \\
\text { examples, etc.) }\end{array}$ & P3, P5, P6, P7, P8 \\
\hline $\begin{array}{l}\text { Increase in the number of sources searched for homework on the } \\
\text { internet and taking a critical stand towards the sources through }\end{array}$ & $\mathrm{P}, \mathrm{P} 6, \mathrm{P} 7, \mathrm{P} 8$ \\
$\begin{array}{l}\text { evaluating their content and choosing among them } \\
\text { Gaining different perspectives about the topic of the essay } \\
\text { evaluated through questioning the argument and searching for } \\
\text { alternatives when a disagreement occurs between the author and } \\
\text { the evaluator regarding content }\end{array}$ & $\mathrm{P} 2, \mathrm{P} 3, \mathrm{P} 8$ \\
\hline $\begin{array}{l}\text { Being able to decide whether a text is worthy of reading in terms of } \\
\text { the strength of the argument and persuasiveness of the pieces of } \\
\text { evidence, samples, etc. }\end{array}$ & $\mathrm{P} 4, \mathrm{P} 8$ \\
\hline $\begin{array}{l}\text { Enabling students to take a critical stance towards the texts they } \\
\text { read and inquire about their reliability and persuasiveness }\end{array}$ & $\mathrm{P} 1, \mathrm{P} 4$ \\
\hline $\begin{array}{l}\text { Learning how to evaluate their writing through evaluating the } \\
\text { writing of others }\end{array}$ & $\mathrm{P} 5, \mathrm{P} 6$ \\
\hline
\end{tabular}

The participants also described the most challenging parts in providing peer feedback. All participants indicated that giving directive feedback was difficult whereas almost all of them $(n=7)$ faced challenges in evaluating the content of a peer's essay due to the following reasons:

"Giving directive feedback was the most difficult one for me because I was afraid of being offensive. Therefore, the question of how to soften my suggestions challenged me a lot" (P1).

"I avoided making suggestions since I was aware that I had a lot of mistakes in my essay. Therefore, I thought that I was not in a position to give directive feedback to someone else's essay" (P3).

"Evaluating the content was challenging for me because it requires having a good knowledge of the issue the author was arguing. While reading the essay, I noticed that I did not know about the issue too much" (P2).

"It was my first experience in giving peer feedback and to me, to be able to give directive feedback, I need to be more competent than my peer. Moreover, we are not accustomed to making suggestions for our friends' essays. I was also worried about how my friend would react to my suggestions since making suggestions is a kind of criticism and criticism is not welcomed in our culture" ( $\left.\mathrm{P}_{5}\right)$.

"Evaluating the content was difficult because a kind of subjective evaluation is necessary and views of the author and the evaluator about the topic could be totally different. Therefore, there are not exact rights and wrongs while evaluating the content, which makes it challenging especially on the part of the evaluator" (P6). 


\section{Discussion and Conclusion}

This single-group pre-test/post-test research study explored how peer-feedback training with a focus on critical comments influenced students' peer feedback practices in a critical reading and writing class and whether there was any relationship between students' writing proficiency and their peer feedback performances. Students' views on the overall process were also investigated to gain an in-depth understanding of the training process and its effects on the students. Findings of the study related to how changes in students' peer-feedback performances correspond to several studies in the relevant field. Hu (2005), Min (2008), and Rahimi (2013) also found that learners who received peer feedback training provided more useful and high-quality feedback in later peer feedback sessions.

In the pre-test session, students' best performance was observed in comments related to essay structure and organization. Similarly, in the post-test, learners were most successful in providing peer feedback related to essay structure and organization. The main reason could be that the writing class the students attended during the first year of the teacher education program familiarized them with the essentials of essay writing, which probably made them pay attention to the issues related to essay structure and organization. On the other hand, the most significant difference between pre- and post-test performances was found in the category of mechanical details. As stated by the participants in the interview session, they were familiar with the issues regarding formal and organizational aspects of writing; therefore, providing feedback related to these criteria was easier for them. It was also confirmed by Rahimi (2013) that students were familiar with the formal aspects of language and did better in terms of providing peer feedback related to formal aspects of writing before receiving peer feedback training.

When it comes to students' performance in providing critical comments, we found a significant improvement; however, most of the participants avoided mentioning fallacies (errors in reasoning) while providing peer feedback. In the interview session, the participants stated that the novelty of the issue (making critical comments) challenged them significantly, especially with regard to detecting and evaluating fallacies, which prevented them from thinking and mentioning the fallacies in the essays they reviewed.

In the pre- and post-test essays, the least successful performance was observed in the category of directives. Some affective factors such as a lack of self-confidence and fear of damaging friendships could be the reason for students' failure in providing directive feedback, as stated by the participants in the interview sessions. They avoided giving directives since they thought their academic levels were not high enough to justify giving suggestions on others' essays and they were also making several mistakes in their own writing.

Disappointingly, this situation did not change even after they received training and practiced providing peer feedback throughout the semester. This finding contradicts the common belief that providing peer feedback is likely to boost students' self-confidence (Lin \& Chien, 2009), as the training the participants received in this study did not contribute to their self-confidence. The educational background of the students and the duration of the study could be considered among the reasons for this situation. During the interview sessions, some participants stated that they were not accustomed to criticizing or giving suggestions to other's works, and therefore, an eight-week training program was not enough for them to internalize these practices. Fear of losing friendships was another major barrier, which was also confirmed by Wang (2014). The question of whether there was a relationship between peer feedback quality and students' writing performance was also investigated. Unsurprisingly, it was found that participants who provided high-quality peer feedback were also successful in L2 writing.

Qualitative data obtained through interviews showed that the participants were content with the peer feedback training they received. They stated that this training contributed to their academic reading and writing skills in many aspects. One of the benefits mentioned by participants was that providing peer feedback enabled them to approach their essays with a critical eye since providing peer feedback increased their 
awareness of the mistakes that can be made throughout the writing process. This finding was supported by several studies in the relevant field (Cao et al., 2019; Lee \& Evans, 2019). Another benefit worth noting was that recognizing weaknesses related to content in others' essays stimulated participants to pay attention to issues like posing a strong argument, supporting it with sound pieces of evidence and real experiences/examples, and finding strong refutation points in their own essays, which led them to conduct indepth research related to the topic they were going to write about.

Overall, the peer feedback training yielded positive results as confirmed by the statistical data and students' statements during interviews. As it was revealed in this study and other studies, peer feedback could be a "potentially valuable aid for its social, cognitive, affective, and methodological benefits" (Rollinson, 2005, p. 23). In particular, giving critical peer feedback (critical comments related to the content) and directive feedback could broaden students' horizons and enable them to approach issues from a different perspective. However, hard work is required on the part of the instructors to encourage students to provide critical feedback and directives since they are not accustomed to these practices, and a longer training period may be required as only eight weeks was allocated for the training in this study, which was regarded as the main limitation of this research. As several participants stated during the interviews, the training period was not enough for them to get used to and adopt a critical approach to peer feedback. This finding could be explained by the heterogeneity of the study group as there were significant differences between participants in terms of L2 writing performance and peer feedback performance. The training challenged participants with lower academic performances, and they stated that they needed extra time to internalize issues related to critical thinking. In fact, the nature of critical thinking poses a great challenge as it is not easy for learners to acquire critical-thinking skills nor are they easy for instructors to teach on a fixed timeline. Both sides must be committed to and engaged in the whole learning and teaching process, where continuity is maintained with strategies that will work in the long run. For favorable results, critical thinking should be an integral part of the teaching program (Edman, 2008). In this study, how training on peer feedback, including critical peer feedback, influenced students' peer feedback performances was explored; however, how students process peer feedback and critical peer feedback in addition to providing peer feedback and critical peer feedback should also be explored in future studies to create a broader understanding of students' peer feedback performances and L2 writing successes through employing critical-thinking skills. In addition, future research should examine how critical peer feedback training affects students' critical peer feedback performances in online settings, as online platforms are an indispensable part of current educational practices and thought to have great potential to encourage students to adopt a more critical stance towards the written work they are revising (Novakovich, 2016). Students' learning processes associated with providing peer feedback can also be closely investigated through reflective journals or think aloud protocols to acquire a better understanding of how training guides students' peer feedback and critical peer feedback performances. 


\section{References}

Atkinson, D. (1997). A critical approach to critical thinking in TESOL. TESOL Quarterly, 31(1), 71-94.

Berggren, J. (2015). Learning from giving feedback: A study of secondary-level students. ELT Journal 69, 5870. https://doi.org/10.1093/elt/ccuo36

Bijami, M., \& Kashef, S. H., \& Nejad, M. S. (2013). Peer feedback in learning English writing advantages and disadvantages. Journal of Studies in Education, 3 (4), 91-97. https://doi.org/10.5296/jse.v3i4.4314

Cao, Z., Yu, S., \& Huang, J. (2019). A qualitative inquiry into undergraduates' learning from giving and receiving peer feedback in L2 writing: Insights from a case study. Studies in Educational Evaluation, 63, 102-112. https://doi.org/10.1016/j.stueduc.2019.08.001

Chen, C. W. (2010). Graduate students' self-reported perspectives regarding peer feedback and feedback from writing consultants. Asia Pacific Education Review, 11, 151-158. https://doi.org/10.1007/s12564010-9081-5

Cho, K., \& MacArthur, C. (2010). Student revision with peer and expert reviewing. Learning and Instruction, 2O, 328-338. https://doi.org/10.1016/j.learninstruc.2009.08.006

Choy, S. C., \& Cheah, P. K. (2009). Teacher perceptions of critical thinking among students and its influence on higher education. International Journal of Teaching and Learning in Higher Education, 20 (2), 198-206. https://files.eric.ed.gov/fulltext/EJ864337.pdf

Crinon, J. (2012). The dynamics of writing and peer review at primary school. Journal of Writing Research, 4(2), 121-154. https://doi.org/10.17239/jowr-2012.04.02.2

Diab, N. M. (2010). Effects of peer- versus self-editing on students' revision of language errors in revised drafts. System, 38, 85-95. https://doi.org/10.1016/j.system.2009.12.008

Edman, L. R. O. (2008). Are they ready yet? Developmental issues in teaching thinking. In D. S. Dunn, J. S. Halonen, \& R. A. Smith (Eds.) Teaching critical thinking in psychology: A handbook of best practices (pp. 35-49).Wiley-Blackwell.

Elder, L. (2007). Our conception of critical thinking. The Critical Thinking Community. https://www.criticalthinking.org/starting/index.cfm \#2425

Elfatihi, M. (2017). A rationale for the integration of critical thinking skills in EFL/ESL instruction. Higher Education of Social Science, 12 (2), 26-31. https://doi.org/10.3968/9702

Elo, S., \& Kyngas, H. (2008). The qualitative content analysis process. Journal of Advanced Nursing 62(1), 107-115. https://doi.org/10.1111/j.136.5-2648.2007.04569.x

Farrah, M. (2012). The impact of peer feedback on improving the writing skills among Hebron University students. An - Najah Univ. J. Res. (Humanities), 26(1), 179-210.

Floyd, C. B. (2011). Critical thinking in a second language. Higher Education Research \& Development, 30(3), 289-302. https://doi.org/10.1080/07294360.2010.501076

Golpour, F. (2014). Critical thinking and EFL learners' performance on different writing modes. Journal of Pan-Pacific Association of Applied Linguistics, 18(1), 103-119. https://files.eric.ed.gov/fulltext/EJ1047523.pdf

Halpern D. (1999) Teaching for critical thinking: Helping college students develop the skills and dispositions of a critical thinker. New Directions for Teaching and Learning, 8o, 69-74. https://doi.org/10.1002/tl.8005 
Hitchcock, D. (2017). Critical thinking as an educational ideal. In On reasoning and argument: Essays in informal logic and on critical thinking. Springer, pp. 477-497. https://doi.org/10.1007/978-3-31953562-3_30

Hu, G. (2005). Using peer review with Chinese ESL student writers. Language Teaching Research, 9, 321342. https://doi.org/10.1191/1362168805/r169oa

Huisman, B., Saab, N., van Driel, J., \& van den Broek, P. (2018). Peer feedback on academic writing: Undergraduate students' peer feedback role, peer feedback perceptions and essay performance. Assessment \& Evaluation in Higher Education, 43(6), 955-968. https://doi.org/10.1080/02602938.2018.1424318

Indah, R. N. (2017). Critical thinking, writing performance and topic familiarity of Indonesian EFL learners. Journal of Language Teaching and Research, 8(2), 229-36. http://dx.doi.org/10.17507/jltr.0802.04

Kamimura, T. (2006). Effects of peer feedback on EFL student writers at different levels of English proficiency: A Japanese context. TESL Canada Journal, 23(2), 12-39. https://doi.org/10.18806/tesl.v23i2.53

Lam, R. (2010). A peer review training workshop: Coaching students to give and evaluate peer feedback. TESL Canada Journal, 27(2), 114. https://doi.org/10.18806/tesl.v27i2.1052

Lee, M-K. \& Evans, M. (2019). Investigating the Operating Mechanisms of the Sources of L2 Writing SelfEfficacy at the Stages of Giving and Receiving Peer Feedback. The Modern Language Journal, 103 (4), 831-847. https://doi.org/10.1111/modl.12598

Liaw, M-L. (2007). Content-based reading and writing for critical thinking skills in an EFL context. English Teaching \& Learning, 31(2), 45-87. https://citeseerx.ist.psu.edu/viewdoc/download?doi=10.1.1.580.288\&rep=rep1\&type=pdf

Lin, G. H. C., \& Chien, P. S. C. (2009). An investigation into effectiveness of peer feedback. Journal of Applied Foreign Languages Fortune Institute of Technology, 3, 79-87. https://eric.ed.gov/?id=ED506179

Lu, R., \& Bol, L. (2007). A comparison of anonymous versus identifiable e-peer review on college student writing performance and the extent of critical feedback. Journal of Interactive Online Learning, 6(2), $100-115$.

Lundstrom, K., \& Baker, W. (2009). To give is better than to receive: The benefits of peer review to the reviewer's own writing. Journal of Second Language Writing, 18, 30-43. https://doi.org/10.1016/j.jslw.2008.06.002

McKinley, J. (2013). Displaying critical thinking in EFL academic writing: A discussion of Japanese to English contrastive rhetoric. RELC Journal, 44(2), 195-208. https://doi.org/10.1177/0033688213488386

Min, H. T. (2006). The effects of training peer review on EFL students' revision types and writing quality. Journal of Second Language Writing, 15(2), 118-141. https://doi.org/10.1016/j.jslw.2006.01.003

Moghaddam, M. M., \& Malekzadeh, S. (2011). Improving L2 writing ability in the light of critical thinking. Theory and Practice in Language Studies, 1(7), 789-797. https://doi.org/10.4304/tpls.1.7.789-797

Nikoopour, J., Amini Farsani, M., \& Nasiri, M. (2011). On the relationship between critical thinking and language learning strategies among Iranian EFL learners. Journal of Technology \& Education, 5(3), 195-199.

Nilson, L. B. (2003) Improving student peer feedback. College Teaching, 51(1), 34-38. https://doi.org/10.1080/87567550309596408

Novakovich, J. (2016). Fostering critical thinking and reflection through blog-mediated peer feedback. Journal of Computer Assisted Learning, 32, 16-30. https://doi.org/10.1111/jcal.12114 
Olshtain, E. (2001). Functional tasks for mastering the mechanics of writing and going just beyond. In M. Celce-Murcia (Ed.) Teaching English as a second or foreign language (pp. 207-219). Heinle \& Heinle.

Polio, C. \& Williams, J. (2009) Teaching and testing writing. In M. H. Long \& C. J. Doughty (Eds.) The handbook of language teaching (pp. 486-518). Blackwell Publishing.

Rahimi, M. (2013). Is training students' reviewers worth its while? A study of how training influences the quality of students' feedback and writing. Language Teaching Research, 17, 67-89. https://doi.org/10.1177/1362168812459151

Raimes, A. (2002). Ten steps in planning a writing course and training teachers of writing. In J. C. Richards \& W. A. Renandya (Eds.) Methodology in language teaching, pp. 306-315. Cambridge University Press.

Rashid, R. A., \& Hashim, R. A. (2008, November 19-21). The relationship between critical thinking and language proficiency of Malaysian undergraduates [Conference proceeding]. Proceeding of the EDUCOM 2008 International Conference, Symposia and Campus Events. Edith Cowan University, Perth Western Australia. https://ro.ecu.edu.au/ceducom/36

Rollinson, P. (2005). Using peer feedback in the ESL writing class. ELT Journal, 59(1), 23-30. https://doi.org/10.1093/elt/ccio03

Stapleton, P. (2001). Assessing critical thinking in the writing of Japanese university students: Insights about assumptions and content familiarity. Written Communication, 18(4), 506-548. https://doi.org/10.1177/0741088301018004004

Yang, M., \& Badger, R., \& Yu, Z. (2006). A comparative study of peer and teacher feedback in Chinese EFL writing class. Journal of Second Language Learning, 15(3), 179-200. https://doi.org/10.1016/j.jslw.2006.09.004

Wang, W. (2014). Students' perceptions of rubric-referenced peer feedback on EFL writing: A longitudinal inquiry. Assessing Writing, 19, 80-96. https://doi.org/10.1016/j.asw.2013.11.008

Working Document (2015). Peer feedback in the writing process handbook. Ministère de l'Éducation, de l'Enseignement supérieur et de la Recherche. https://www.eslinsight.qc.ca/IMG/pdf/8_Peer_Feedback_Handbook 2015.pdf

Zhao, H. (2010). Investigating learners' use and understanding of peer and teacher feedback on writing: A comparative study in a Chinese English writing classroom. Assessing Writing 15, 3-17. https://doi.org/10.1016/j.asw.2010.01.002

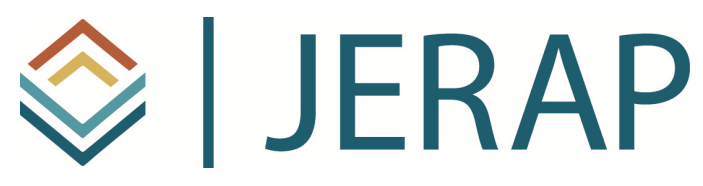

The Journal of Educational Research and Practice is a peerreviewed journal that provides a forum for studies and dialogue about developments and change in the field of education and learning. The journal includes research and related content that examine current relevant educational issues and processes. The aim is to provide readers with knowledge and with strategies to use that knowledge in educational or learning environments. JERAP focuses on education at all levels and in any setting, and includes peer-reviewed research reports, commentaries, book reviews, interviews of prominent individuals, and reports about educational practice. The journal is sponsored by the Richard W. Riley College of Education and Leadership at Walden University, and publication in JERAP is always free to authors and readers. 